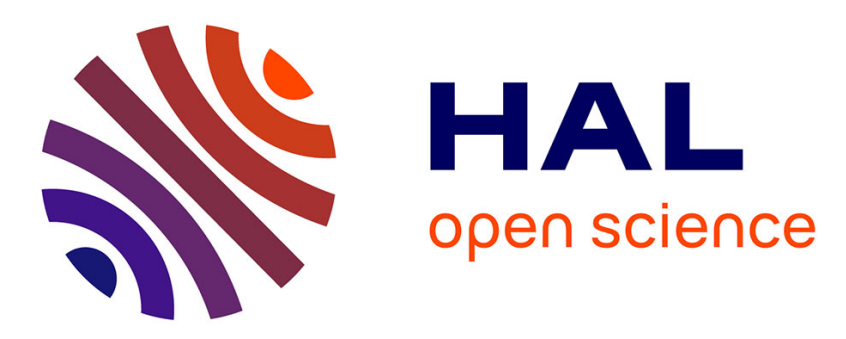

\title{
The Limitations on Military Activities by Third States in the EEZ Resulting from Environmental Law
}

\author{
Pascale Ricard
}

\section{To cite this version:}

Pascale Ricard. The Limitations on Military Activities by Third States in the EEZ Resulting from Environmental Law. International Journal of Marine and Coastal Law, 2019, 34 (1), pp. 144-165. 10.1163/15718085-23341038. hal-02514646

\section{HAL Id: hal-02514646 \\ https://hal.science/hal-02514646}

Submitted on 22 Mar 2020

HAL is a multi-disciplinary open access archive for the deposit and dissemination of scientific research documents, whether they are published or not. The documents may come from teaching and research institutions in France or abroad, or from public or private research centers.
L'archive ouverte pluridisciplinaire HAL, est destinée au dépôt et à la diffusion de documents scientifiques de niveau recherche, publiés ou non, émanant des établissements d'enseignement et de recherche français ou étrangers, des laboratoires publics ou privés. 


\title{
The Limitations on Military Activities by Third States in the EEZ Resulting from Environmental Law
}

\author{
Pascale Ricard \\ University Paris I, Paris, France \\ Pascale.Ricard@etu.univ-paris1.fr
}

\begin{abstract}
In the Exclusive Economic Zone (EEZ), the supposed freedom of states to conduct military activities encounters the rights and duties of coastal states regarding the conservation of marine resources and preservation of the environment. This article focuses on the relationship between these two specific but not always compatible interests and asks: how should they be combined? Could international environmental law rules be interpreted as a limitation to the conduct of military activities in the EEZ? What are the concrete obligations of states to fulfil their environmental duties, and how far are they compatible with the conduct of other activities? The 'due diligence' obligation to protect the marine environment is interpreted as going further than the 'due regard' standard enshrined in Articles 56 and 58 of the LOSC. Accordingly, this article assumes that it is a positive obligation, implying specific consequences, such as the conduct of environmental impact assessments when the activity risks causing damage.
\end{abstract}

\section{Keywords}

exclusive economic zone (EEZ) - protection of the marine environment - military activities pollution - due diligence obligation

\section{Introduction}

Military Activities, the Protection of the Marine Environment and the EEZ Regime

During a military exercise conducted by the American and Australian navies in 2013, bombs were dropped on the Great Barrier Reef, which is classified by the United Nations Educational, Scientific and Cultural Organization (UNESCO) as a World Heritage site.1 US Navy jets were forced to drop the bombs because civilian boats were spotted near their original target (two bombs were inert and two carried explosives but were not armed). This incident was strongly criticized by environmental associations (such as the World Wide Fund for Nature (WWF)), arguing that military activities should be conducted with consideration for the conservation of the marine environment, especially in marine reserves.2 This incident illustrates the potential conflicts between different uses of the sea, here environmental protection and military activities. 3 Military activities may indeed have adverse effects on the

1 UNESCO Convention Concerning the Protection of the World Cultural and Natural Heritage, (Paris, 16 November 1972, in force 15 December 1975) 1037 UNTS 151. The Great Barrier Reef was inscribed on the World Heritage List in 1981 (Decision CONF 003 VIII.15, Nominations to the World Heritage List (inscribed sites) available at http://whc.unesco.org/en/decisions/5236/, accessed 20 September 2018).

2 O Milman, 'Great Barrier Reef bombing the latest mishap from "war games", The Guardian, 22 July 2013.

3 The French navy published online a Guide assessing the environmental impact of military activities in different sites of the Natura 2000 European network of protected areas. It is a useful tool for providing an idea of the 
environment. For example, sonar, underwater detonations and acoustic wave emissions are important sources of noise pollution, having a detrimental effect on marine mammals, turtles, and also coral reefs. 4

Even when the impact on the marine environment is minor or uncertain, the cumulative impact of such activities may be significant and is not always taken into account when assessing the effects of a particular activity at sea. For instance, the accumulation of waste (nuclear and other) in the Arctic Ocean, dumped during the Cold War or transported by currents, is an illustration of the necessity to consider the cumulative impact of any source of pollution. Such accumulation could entail dramatic environmental effects, given the fragility of the environment and the current melting of the ice caps.

This paper mainly considers military activities of non-coastal states in times of peace, such as exercises, experiments or tests of materials in or near the EEZ of another state.5 Some of the principal issues for consideration are the multiple launches of intercontinental ballistic missiles by North Korea, some of which have ended up in Japan's EEZ.6 The paper will also briefly mention the case of operational military activities, including in times of war, in order to compare the legal framework applicable in both situations.

As its Preamble illustrates, the United Nations Convention on the Law of the Sea (LOSC or the Convention) 7 remains one of the most complete international instruments as regards the protection and preservation of the marine environment: 'Recognizing the desirability of establishing through this Convention [...] a legal order for the seas and oceans which will facilitate international communications, and will promote the peaceful uses of the seas and oceans, the equitable and efficient utilization of their resources, the conservation of their living resources, and the study, protection and preservation of the marine environment'. This environmental dimension influences the whole Convention, as shown in its Part XII on the marine environment, but also when establishing the EEZ regime. The EEZ is of a hybrid nature, standing at the crossroads of territorial sovereignty and freedom of the high seas. As Kraska notes, 'the negotiation of [the] LOSC struck a balance between coastal-state and userstate interests'.8

Ecological considerations are increasingly important internationally. However, environmental limitations imposed on military activities in the EEZ are not specially mentioned in the LOSC or other relevant instruments. This is because the freedom to conduct military activities in the EEZ itself is not incorporated in the LOSC, which gives rise to

potential operational effect of these activities on the marine environment and it illustrates the need for an articulation between military activities and protected areas. See L Germain (Coord. gén.), Référentiel technique des activités de la défense nationale pour la gestion dans les sites Natura 2000 en mer, Tome 1, Activités en mer (Agence des aires marines protégées, avec la collaboration du Ministère de la Défense et les conseils du Muséum National d'Histoire Naturelle, janvier 2014) 1-124.

4 According to Kraska, even where there is no proof of the potential danger of sonars on cetaceans, the US Navy applies voluntary conservation measures. See J Kraska, 'Resources Rights and Environmental Protection in the Exclusive Economic Zone: The Functional Approach to Naval Operations' in P Dutton (ed), Military Activities in the EEZ. A U.S.-China Dialogue on Security and International Law in the Maritime Commons (Naval War College/China Maritime Studies Institute, Newport, 2010) 75-88, at p. 82.

5 Article 57 of the LOSC: 'The exclusive economic zone shall not extend beyond 200 nautical miles from the baselines from which the breadth of the territorial sea is measured'.

6 Tests from 28 July 2017 and 28 November 2017. See W Worley, "North Korea launches "ICBM" which may have landed within 200 miles of Japan coast', The Independent, 28 July 2017; T Higgins, 'North Korean missile lands in sea of Japan, Pentagon says', $C N B C$, 28 November 2017.

7 United Nations Convention on the Law of the Sea (Montego Bay, 10 December 1982, in force 16 November 1994) 1833 UNTS 396.

8 Kraska (n 4), at p. 75. 
differing interpretations.9 The right to conduct military activities in the EEZ was, indeed, the subject of much discussion at the third United Nations Conference on the Law of the Sea (UNCLOS III) and still involves uncertainties. 10 Several states (especially from Latin America and Asia) considered that these activities require the consent of the coastal state. Other states pled for a complete freedom to conduct such activities in the EEZ.

\section{Competing Rights and Interests in the EEZ: Are Some Interests Superior to Others?}

Articles 56 and 58 of the LOSC provide a clear illustration of the compromise reached on the EEZ regime during UNCLOS III. Article 56 sets out the sovereign rights and jurisdiction of the coastal state, including as regards the protection and preservation of the marine environment, and the conservation of living resources. Article 58 mirrors Article 56, recalling the rights and duties of non-coastal states in this hybrid area. However, the balance struck between competing rights and interests in the LOSC leaves the question of conflicts between these rights and duties unresolved. Are some rights and interests more important than others? Do the rights and duties of coastal states have 'priority' over the freedoms and rights of the non-coastal states? Moreover, can we consider that the environmental interests are 'superior' to other interests, as for instance the right of non-coastal states to conduct military activities? The Seabed Chamber of the International Tribunal for the Law of the Sea (ITLOS) stated on 1 February 2011, in its first advisory opinion regarding the Responsibility of contracting States for the activities conducted in the Area, that the obligations related to the conservation of the environment in the high seas and in the deep seabed are of an erga omnes character.11 The erga omnes and customary nature of these obligations (see infra) surely influences their relationship with the rights and obligations of third states, including the right to conduct military activities in the EEZ.

Although the LOSC is silent on how to solve and prevent such conflicts of rights or interests, some indications can be found in Article 59 dealing with the 'resolution of conflicts regarding the attribution of rights and jurisdiction in the exclusive economic zone'. This Article provides that '[i]n cases where this Convention does not attribute rights or jurisdiction to the coastal State or to other States within the exclusive economic zone, and a conflict arises between the interests of the coastal State and any other State or States, the conflict should be resolved on the basis of equity and in the light of all the relevant circumstances, taking into account the respective importance of the interests involved to the parties as well as to the international community as a whole'. The reference to the relative importance of the interests involved and to the interests of the international community as a whole is noteworthy. The former lead to the necessity to take into account the environmental and conservational rights and duties of the coastal states, as indicated in Article 6 of the 1997 Convention on the Law of Non-navigational Uses of International Watercourses, 12 which concerns the 'factors relevant

9 See JN Moore, MH Nordquist, S N Nandan and S Rosenne (eds), United Nations Convention on the Law of the Sea 1982. A Commentary, Vol. III (Martinus Nijhoff, Leiden, 1995), at p. 91.

10 See J Geng, 'The Legality of Foreign Military Activities in the Exclusive Economic Zone under UNCLOS' (2012) 28(74) Utrecht Journal of International and European Law 22-30, at p. 26. As the author shows, states have made contradictory declarations regarding the conduct of military activities in the EEZ. Some, like Brazil, affirm that the conduct of such activities must be preceded by the consent of the coastal state, whereas others, like the UK, consider that military activities in the EEZ are part of the freedom of the high seas applicable in the EEZ. For Orrego Vicuña, the issue of military activities in the EEZ was 'one of the most difficult aspects of the work of the third Conference on the Law of the Sea'. F Orrego Vicuña, The Exclusive Economic Zone. Regime and Legal Nature under International Law (Cambridge University Press, Cambridge, 1989), at p. 108.

11 Responsibilities and obligations of States sponsoring persons and entities with respect to activities in the Area (Request for Advisory Opinion submitted to the Seabed Disputes Chamber), Advisory Opinion [2011] Case No. 17 , at [180].

12 Convention on the Law of Non-navigational Uses of International Watercourses (New York, 21 May 1997, in force 17 August 2014) 36 ILM 700 (1997). 
to equitable and reasonable utilization' of international watercourses. The relevant factors and circumstances to be considered include, indeed, the '[c]onservation, protection, development and economy of use of the water resources of the watercourse and the cost of measures taken to that effect', and 'the availability of alternatives, of comparable value, to a particular planned or existing use'.13 Then, the reference to 'the international community as a whole' suggests that, in balancing the rights and duties of the coastal and non-coastal states, the 'interests' of the whole international community must be considered. The conservation of the living resources and the protection and preservation of the environment are certainly among those interests. It is important not only for the coastal state but also for all states to have a healthy ocean with abundant living resources. Thus, according to Beckman and Davenport, there is support for certain military activities being regarded as 'unattributed rights' subject to resolution of conflicts under Article 59, which must be considered here.14 Moreover, these authors recall the 'purpose' of the EEZ, which is a 'resources zone', aimed at giving 'coastal States the sovereign rights for the purpose of exploring and exploiting and conserving and managing the natural resources in their EEZs [... $]^{\star} .15$ According to Orrego Vicuña, the hybrid and functional nature of the EEZ has consequences for the limitation of activities by third states in this area: at least, 'the limitations of military uses in the EEZ are greater than those applied to similar activities carried out in the high seas'.16 Furthermore, Dupuy and Vignes give an original definition of the EEZ as a 'zone de protection écologique à finalité économique' (an area under ecological protection for economic purposes).17

The combination of these diverse elements pleads in favour of the pre-eminence of the environmental rights, duties and, more broadly, interests of the coastal states over the rights and freedoms of the non-coastal states within the EEZ. According to Geng, finally, 'circumstances matter and the implication is that there are many variables in determining whether certain military activities are permissible in the EEZ of a state, such as the scope and nature of the activity, the proximity of the vessel to the coastal state, and the impact on the marine environment'.18 In addition, Bateman calls for a principle of '[n]on-interference with the coastal State's duty to preserve and protect the marine environment of the EEZ', adding that

[f]or example, scheduling an exercise in an area of intensive fishing activity declared by the coastal State, or in a marine park or marine protected area declared by the coastal State as required by article 194(5) of LOSC, could be considered not to have due regard to the rights and duties of the coastal State. Similarly, the military activities of other States should not interfere with the legitimate surveillance and enforcement activities of the coastal State aimed at protecting its rights or preventing pollution in the EEZ.19

13 Article 6(3) adds: 'The weight to be given to each factor is to be determined by its importance in comparison with that of other relevant factors. In determining what is a reasonable and equitable use, all relevant factors are to be considered together and a conclusion reached on the basis of the whole'.

14 See R Beckman and T Davenport, 'Securing the Ocean for the Next Generation' in Proceedings from the 2012 LOSI-KIOST Conference on Securing the Ocean for the Next Generation (Law of the Sea Institute, Seoul, May 2012) 1-41, at p. 26.

15 Ibid., at p. 27.

16 Orrego Vicuña (n 10), at p. 111.

${ }_{17}$ R J Dupuy and D Vignes, Traité du nouveau droit de la mer (Economica, Paris, 1985), at p. 1015.

${ }_{18}$ Geng (n 10), at p. 27.

${ }_{19}$ S Bateman, 'The regime of the EEZ: military activities and the need for compromise?' in TM Ndiaye and R Wolfrum (eds), Law of the Sea, Environmental Law and Settlement of Disputes (Martinus Nijhoff, Leiden, 2007) 569-582, at p. 573. 
In any case, the uncertainty surrounding the balance of competing rights leads to an 'unsatisfactory situation for operational commanders', and underscores the need for some clarification.20

\section{A Question of Degree}

Environmental limitations exist nowadays for almost every activity at sea, including navigation. Even though the exercise of military activities in the EEZ of another state is not prohibited in international law, environmental imperatives clearly could set a limit to such activities, even if this limit is blurred. The question, however, is about the extent of that limitation. When and to what extent could the protection of the marine environment impose a limit on the exercise of military activities in the EEZ?

First, we focus on the law of the sea and international environmental law as the relevant legal framework in which to study the environmental limitations on military activities in the EEZ by third states and the extent to which environmental considerations could restrict the conduct of military activities in this zone. We then examine the practical consequences of the applicability of those provisions or customary norms, not only for the coastal state, but also for the state conducting the military activity.

\section{Military Activities as a Potential Threat to the Marine Environment: The General Legal Framework in Time of Peace}

\section{Treaty Law as a Limit to Military Exercises and Experiments}

Provisions of the LOSC

Certain general and specific provisions of the LOSC could apply to the launching of weapons and inter-continental ballistic missiles, as well as to the introduction of substances into the EEZ of another state. First of all, it is noteworthy that Article 1 of the LOSC defines the notion of pollution of the marine environment broadly as 'the introduction by man, directly or indirectly, of substances or energy into the marine environment, which results or is likely to result in [...] harm to living resources and marine life'. This definition seems to apply to various types of pollution and activities, leading to a potentially broad interpretation of this provision.

As regards the launch of intercontinental ballistic missiles, especially in view of the recent situation involving North Korea and Japan, it may be asked whether Article 210 of the LOSC might be of any help, interpreting this launch as potential 'dumping at sea'. Indeed, Article 210(5) and (6) states that '[d]umping within the exclusive economic zone shall not be carried out without the express prior approval of the coastal State, which has the right to permit, regulate and control such dumping after due consideration of the matter with other States which by reason of their geographical situation may be adversely affected thereby', and '[n]ational laws, regulations and measures shall be no less effective in preventing, reducing and controlling such pollution than the global rules and standards'. To determine whether the launching of missiles or weapons at sea could be interpreted as dumping, we need to go back to Article 1(5)(b) of the LOSC, according to which dumping 'does not include: [...] (ii) placement of matter for a purpose other than the mere disposal thereof, provided that such placement is not contrary to the aims of this Convention'. This clarification is of particular importance: at first glance, it rules out the potential application of Article 210. However, the second part of the sentence, relating to the aims of the Convention, shows the potential applicability of Article 210 to dumping: the 'aims of the Convention' include, in addition to 
the creation of a peaceful and equitable order for the seas, the protection and preservation of the marine environment, as illustrated in the preamble of the LOSC. The dumping of a ballistic missile or other weapon at sea could thus be interpreted as being contrary to the environmental but also peaceful aims of the Convention, leading to the prohibition of such activities.

The LOSC also deals with other sources of pollution: Article 211 on pollution by vessels and 212(1) on pollution of the marine environment from or through the atmosphere could apply to military exercises involving nuclear-powered ships or other vessels or aircraft, depending on the pollutant effects of those activities.

Of fundamental importance are also the general obligations of the LOSC, especially Articles 192, 194 and 300. Article 192 consecrates the obligation, for 'States' in general, to protect and preserve the marine environment. Article 194 is particularly rich as it provides for the principle of prevention, dealing with all sources of pollution. According to its paragraphs 4 and 5:

[i]n taking measures to prevent, reduce or control pollution of the marine environment, States shall refrain from unjustifiable interference with activities carried out by other States in the exercise of their rights and in pursuance of their duties [...]. The measures taken in accordance with this Part shall include those necessary to protect and preserve rare or fragile ecosystems as well as the habitat of depleted, threatened or endangered species and other forms of marine life.

Finally, Article 300 deals with good faith and abuse of rights. The notion of 'abuse of rights' forms a limit to the cohabitation of concurrent rights in the EEZ.

These general obligations are currently increasingly developed and used by courts and tribunals. For instance, in the Duzgit Integrity Arbitration, the arbitral tribunal stated that '[t] he Convention is a multilateral treaty which establishes a framework of rules that apply to all States parties. In certain circumstances, the provisions of the Convention apply in such a way that a relationship of a bilateral character between two parties is created',21 and added that 'Article 300 is an overarching provision which applies to all provisions of the Convention. It is not a stand-alone provision'.22 Similarly, in the South China Sea Arbitration (China v. Philippines), the arbitral tribunal interpreted the general obligations of the LOSC on the protection and preservation of the marine environment, i.e., Articles 192 and 194, as part of a general 'due diligence' obligation to protect and preserve the marine environment, in the light of other requirements of international environmental law, including treaty law relating to protected species.23 These general obligations establish a link between all the provisions of the Convention, but also between its diverse goals, and between treaty law and customary law.

Other Relevant International or Regional Conventions

Other global or regional Conventions could be relevant while considering the environmental limitations on military activities in the EEZ. First, with respect to global Conventions, the

21 The Permanent Court of Arbitration (PCA) Case No. 2014-07, The Duzgit Integrity Arbitration (Malta v. São Tomé and Príncipe), Award of 5 September 2016, at [148].

22 Ibid., at [216].

23 PCA Case No. 2013-19 in the matter of The South China Sea Arbitration before an arbitral tribunal constituted under Annex VII to the 1982 United Nations Convention on the Law of the Sea between the Republic of Philippines and The People's Republic of China, Award of 12 July 2016, at [959]: 'The Tribunal has noted that it considers the duty to prevent the harvest of endangered species follows from Article 192, read against the background of other applicable international law. The Tribunal considers that this general obligation is given particular shape in the context of fragile ecosystems by Article 194(5)'. 
Protocol (1996) 24 to the London Convention (1972)25 on the prevention of marine pollution by dumping of wastes and other matter use the same definition of dumping as the LOSC, providing that dumping should not apply to the 'placement of matter for a purpose other than the mere disposal thereof' (Article 1(2)). This means, in the same way as in the LOSC, that the interpretation of this definition depends on the aim of the Protocol, which is to "promote the effective control of all sources of pollution of the marine environment [...]' (Article 2). This Protocol consecrates a precautionary approach: states shall take preventive measures 'even when there is no conclusive evidence to prove a causal relation between inputs and their effects'. It also invokes the 'polluter pays' principle (Article 3). If the firing of a ballistic missile into the EEZ of another state is to be considered as a potential 'dumping' at sea, it would then fall under the prohibition of the dumping of any waste or other matter provided by this Protocol, with the exception of those not listed in Annex 1, requiring special permits.

Other Conventions deserve to be mentioned, such as the 1986 Convention on Early Notification of a Nuclear Accident 26 which could be of relevance, for instance, when nuclearpowered submarines encounter difficulties at sea. It sets out a notification system for nuclear accidents, which have the potential for international transboundary release or radioactivity that could be of radiological safety significance for another state.

Specific global conventions on the preservation of marine species constitute the legal basis for the adoption of conservation measures by coastal states, potentially limiting the freedoms of other states in their EEZ: for example, the Convention on Biological Diversity27 is the basis for the creation of marine protected areas (Article 8), and the conduct of environmental impact assessment and minimization of adverse impacts (Article 14). The Bonn Convention on migratory species (1979) 28 deals with the conservation of endangered species in the 'Range States'. Conventions dealing with the protection of marine mammals 29 are also worth mentioning, bearing in mind the potential effects of military activities on these species and especially the effects resulting from noise pollution.

Additionally, the Regional Seas Conventions, created under the United Nations Environment Program (UNEP) in work ongoing since the 1970s, often contain useful provisions. The 1992 OSPAR Convention, 30 for instance, provides for the prevention and elimination of pollution by dumping or incineration (Annex II), but also the dumping of lowand intermediate-level radioactive substances, including wastes (Article 3), and the obligation to prevent transboundary pollution (Article 21). It is important to recall that these regional conventions are only applicable for states parties to the agreements and that their contents vary. For instance, the NOWPAP 31 (1994, North West Pacific Action Plan) and the

241996 Protocol to the Convention on the Prevention of Marine Pollution by Dumping of Wastes and Other Matter (London, 11 July 1996, in force 24 March 2006) 36 ILM 1 (1997).

25 Convention on the Prevention of Marine Pollution by Dumping of Wastes and Other Matter (London, 29 December 1992, in force 30 August 1975), 1046 UNTS 120.

${ }_{26}$ Convention on Early Notification of a Nuclear Accident (Vienna, 26 September 1986, in force 27 October 1986), 1439 UNTS 275.

${ }_{27}$ Convention on Biological Diversity (Rio de Janeiro, 5 June 1992, in force 29 December 1993), 1760 UNTS 79.

${ }_{28}$ Convention on the Conservation of Migratory Species of Wild Animals (Bonn, 23 June 1979, in force 1 November 1983), 1651 UNTS 333.

29 As, for instance, the International Convention for the Regulation of Whaling (Washington, 2 December 1946, in force 10 November 1948), 161 UNTS 72.

30 Convention for the Protection of the Marine Environment of the North-East Atlantic (Paris, 22 September 1992, in force 25 March 1998), 2354 UNTS 67.

31 Action Plan for the Protection, Management, and Development of the Marine and Coastal Environment of the North-West Pacific Region. See the website of the Action Plan available at http://www.nowpap.org/, accessed 20 September 2018. 
COBSEA 32 (1981, Coordinating Body on the Seas of East Asia), which are non legally binding coordinating programmes of action for the protection of the marine environment, do not contain recommendations on dumping.

However, to overcome the uncertainties of variable interpretations and the limits of overly specific or non-universal adoption of global and regional Conventions, we need to supplement those elements with the principles of customary international environmental law, especially with regard to the 'due diligence' obligation.

\section{The Environmental 'Due Diligence' Obligation in Customary International Law}

The development of a 'due diligence' obligation dedicated to the protection of the marine environment derives from two well-known decisions: the Trail Smelter arbitration,33 of 1941, and the Corfu Channel case34 of 1949. In the former, a tribunal awarded damages to the USA and prescribed a regime for controlling future emissions from a Canadian smelter which had caused air pollution damage, stating that 'no State has the right to use or permit the use of its territory in such a manner as to cause injury by fumes in or to the territory of another'. According to the International Court of Justice (ICJ), in the latter case, it is: 'every State's obligation not to allow knowingly its territory to be used for acts contrary to the rights of other States'. 35 This principle was also developed in Principle 21 of the Stockholm Declaration in 197236, reiterated in Principle 2 of the 1992 Rio Declaration37: 'States have [...] the responsibility to ensure that activities within their jurisdiction or control do not cause damage to the environment of other States or of areas beyond the limits of national jurisdiction'. Although these "principles" are not legally binding, one can surely understand that they appear as a potential limitation on military activities in the EEZ of a coastal state, as they reflect not only customary international law, but also the legally binding obligation set out in the LOSC Article 194(2), mentioned above.

Indeed, the relatively recent case law of the ICJ is particularly relevant as regards the development of a 'due diligence' obligation for the protection of the environment.38 The most famous and decisive ICJ decision is the Pulp Mills case of 2010, recalling the Corfu Channel statement:

[t]he Court points out that the principle of prevention, as a customary rule, has its origins in the due diligence that is required of a State in its territory. [...] A State is thus obliged to use all the means at its disposal in order to avoid activities taking place in its territory, or in any area under its jurisdiction, causing significant damage to the environment of another State. 39

In the decision concerning Certain activities and construction of a road (Costa Rica v. Nicaragua), in 2015, the ICJ added that: '[a]lthough the Court's statement in the Pulp Mills

\footnotetext{
32 Action Plan for the Protection and Sustainable Development of the Marine and Coastal Areas of the East Asian Region. See the website of the Action Plan available at https://www.cobsea.org/, accessed 20 September 2018.

33 Trail Smelter Case (United States, Canada) [1941] Reports of International Arbitral Awards vol. III, pp. 19051982.

${ }_{34}$ Corfu Channel case (United Kingdom v. Albania) [1949] ICJ Rep 4.

35 Ibid., at p. 22 (emphasis added).

36 Declaration of the United Nations Conference on the Human Environment (Stockholm, 16 June 1972), UN

Doc. A/Conf.48/14/Rev. 1(1973), 11 ILM 1416 (1972).

37 Rio Declaration on Environment and Development (Rio de Janeiro, 13 June 1992), UN Doc. A/CONF.151/26 (vol. I), 31 ILM 874 (1992).

38 Gabčikovo Nagymaros Project (Hungary v. Slovakia) [1997] ICJ Rep 7, at [112].

39 Pulp Mills on the River Uruguay (Argentina v. Uruguay) [2010] ICJ Rep 14, at [101].
} 
case refers to industrial activities, the underlying principle applies generally to proposed activities which may have a significant adverse impact in a transboundary context'.40

Other case law strengthens the existence of a 'due diligence' requirement from states with regard to the protection of the environment and extends it to the marine environment and biological resources. Indeed, the two advisory opinions of the International Tribunal for the Law of the Sea (ITLOS), i.e., Request for an Advisory Opinion Submitted by the Sub-Regional Fisheries Commission (SRFC) of 2 April 2015, 41 and Responsibilities and Obligations of States [...], advisory opinion of the Seabed Disputes Chamber of 1 February 2011, strengthen the existence and the content of the 'due diligence' obligation regarding the marine environment. The latter explains that "[t]he notions of obligations "of due diligence" and obligations "of conduct" are connected', and that the 'due diligence' obligation is an obligation of means or best efforts and not an obligation of result. It contains, therefore, 'an obligation to adopt regulatory or administrative measures [...] and to enforce them'.42 It also added that the 'due diligence' requirement is variable, and may require different standards depending on the risk of the activity, but also on the capacities of the operator concerned. The measures taken by the state or operator shall be 'reasonably appropriate', 43 which attests to their flexibility and adaptability to the relevant circumstances.

In the South China Sea Arbitration (China v. Philippines) case, as already mentioned, the arbitral tribunal interpreted the general obligations of the LOSC on the protection and preservation of the marine environment as part of the 'due diligence' obligation, in the light of other requirements of international environmental law, including Article 194 of the Convention and other provisions on protected species. Thus,

the Tribunal considers [...] that Article 192 imposes a due diligence obligation to take those "measures necessary to protect and preserve rare or fragile ecosystems $[\ldots]$ and other forms of marine life." Therefore, in addition to preventing the direct harvesting of species recognized as being threatened with extinction, Article 192 extends to the prevention of harms that would affect depleted, threatened, or endangered species indirectly through the destruction of their habitat.44

It expressly consecrated the 'due diligence' obligation to protect and preserve the marine environment.

All in all, there exists a customary law obligation to exercise due diligence in order to avoid causing significant transboundary harm and to actively protect the marine environment. In the present author's view, due diligence differs from due regard, and goes further. It also goes beyond the prevention principle, as it is a positive obligation to act, not only to refrain from acting. The violation of the 'due diligence' requirement is to be appreciated in concreto, taking into account all the circumstances (legal, scientific and technical). The state of origin shall 'take all appropriate measures to prevent significant trans-boundary harm or at any event to minimize the risk thereof' .45 This includes the use of 'best environmental practices' and 'best technologies', with 'an evolving standard of technology and regulation', as Birnie,

40 Certain Activities Carried Out by Nicaragua in the Border Area (Costa Rica v. Nicaragua); and Construction of a Road in Costa Rica along the San Juan River (Nicaragua v. Costal Rica) [2015] ICJ Rep 665, at [104].

41 Request for an Advisory Opinion Submitted by the Sub-regional Fisheries Commission (SRFC), Advisory Opinion [2015], Case ${ }^{\circ} 21$, (ITLOS, 2 April 2015).

42 Responsibilities and obligations of States sponsoring persons and entities... (n 11), at [110-111].

43 Ibid., at [119-120].

44 South China Sea Arbitration (n 23) at [959].

45 Prevention of Transboundary Harm from Hazardous Activities, International Law Commission, 2001, Official Records of the General Assembly, Fifty-sixth Session, Supplement No. 10, A/56/10. 
Boyle and Redgwell recall. 46 It also implies the conduct of an environmental impact assessment where there is a risk of significant harm (see infra). The 'due diligence' obligation does apply to all activities having a transboundary impact, so military activities in the EEZ of a third state are not a priori excluded, either geographically or substantially. Indeed, it 'applies generally to proposed activities which may have a significant adverse impact in a transboundary context', including in time of war.47

\section{Practical Consequences of Those Environmental Limitations on Military Activities for Coastal and Non-Coastal States}

\section{Consequences for the Coastal State: Adoption and Enforcement of Laws and Regulations Dealing with Marine Environmental Protection}

The 'due diligence' obligation contains 'an obligation to adopt regulatory or administrative measures [...] and enforce them'.48 The first aspect of due diligence, read in the light of Articles 56 and 58 of the LOSC, is that the coastal state has a duty to adopt laws and regulations in order to actively protect and preserve the marine environment.49 These laws and regulations could consist of any measures aimed at protecting and preserving the marine environment: for example, the creation of a protected area, the prohibition of certain activities in sensitive areas, the technical regulation governing the material or vessel used. One may wonder, though, whether the coastal state can directly prohibit any military activities by noncoastal states in its EEZ, or put in place an authorization regime? Could such a regulation be effective through the creation of a marine protected area (MPA) in the EEZ of a coastal state?50

The creation of an MPA could indeed provide for measures limiting military activities, if specified in the related constituent instrument. One might, however, worry about the current tendency to create ever-larger protected areas, covering the entire EEZ, and illustrating the creeping jurisdiction of coastal states in the name of environmental protection.51 The Chagos Marine Protected Area case is a clear illustration of this phenomenon: the MPA is being used as an instrument to consolidate the sovereignty of the United Kingdom in this area. However, in this case, the UK had exempted Diego Garcia Island, which is a US military base situated in the contested EEZ.52

${ }_{46}$ P Birnie, A Boyle and C Redgwell, International Law and the Environment (3rd ed., Oxford University Press, Oxford, 2009), at p. 148. For the authors, '[i]f the main advantage of due diligence is its flexibility and responsiveness to circumstances, the main disadvantage of a generalized formulation is that it offers limited guidance on what legislation or technology are required in specific cases'. Ibid., at p. 149.

47 See infra, last subsection, for the specifics of this situation. K Mollard-Bennelier, La protection de l'environnement en temps de conflits armés (Pedone, Paris, 2001), at p. 340.

48 Responsibilities and obligations of States sponsoring persons and entities... (n 11), at [111].

49 It is possible to draw a link with the sovereign fisheries rights of the coastal state, even though the two fields (environmental protection and fisheries activities) are generally studied separately. Indeed, the protection of the marine environment is a prerequisite for sustainable fisheries. See in this volume the contribution of T Scovazzi. 50 The creation of MPAs is recommended by the Convention on Biological Diversity: see Article 8 of this Convention (n 28), stressed by the derived implementations of this Convention by the Conferences of the parties to this Convention in their recommendations and Aichi Targets.

51 See N Monebhurrum, 'Creating Marine Protected Areas to Assert Territorial Jurisdiction against the Right of Abode of Native Populations: The Case of the Chagos Archipelago' in EM Vazquez Gomez and C Cinelli (eds), Regional Strategies to Maritime Security. A Comparative Perspective (Tirant lo Blanch, Valencia, 2014) 79-99, at p. 90 .

52 PCA Case No. 2011-03 in the matter of The Chagos Marine Protected Area Arbitration before an arbitral tribunal constituted under Annex VII to the 1982 United Nations Convention on the Law of the Sea between the Republic of Mauritius and the United Kingdom of Great Britain and Northern Ireland, Award of 18 March 2015, at [533]. 
The second component of the 'due diligence' requirement is a duty of surveillance and enforcement, especially if the state is aware of any polluting activities. In the South China Sea Arbitration, the arbitral tribunal states that 'adopting appropriate rules and measures to prohibit a harmful practice is only one component of the due diligence required by States [...]. China, despite its rules on the protection of giant clams, and on the preservation of the coral reef environment generally, was fully aware of the practice and has actively tolerated it as a means to exploit the living resources of the reefs in the months prior to those reefs succumbing to the near permanent destruction brought about by the island-building activities discussed in Section 4'.53 The supposed awareness of the coastal state is thus considered as a means to ensure that it meets its control and surveillance obligations.

Where a vessel is involved, which is not always the case for military activities such as the testing of weapons, Article 73 of the LOSC, dealing with 'Enforcement of laws and regulations of the coastal State', is also relevant and applicable. Moreover, LOSC Articles 95, 96 and 236,54 on warship immunity, could interfere with the process of enforcement. However, even when the immunity applies, it is at a later stage of enforcement. The government's ships, however, generally apply these obligations voluntarily even if it is not directly bound to do so. The difficulty regarding enforcement nonetheless remains when no vessel is part of the activity.

As a partial conclusion, it is possible to interpret the 'due diligence' obligation of the coastal state as a duty to protect its interests regarding the exploitation and preservation of all the resources of its EEZ. Then, the degree to which the coastal state can adopt and enforce specific laws and regulations must be proportionate to these objectives. As Oxman states: 'on pourrait difficilement faire admettre un exercice militaire qui cause un dommage considérable à une importante ressource naturelle que l'État côtier est en train d'exploiter'.55

\section{Procedural Consequences for the State Conducting Military Activities}

The state conducting military activities has at least to implement certain procedural obligations: to conduct an environmental impact assessment and to notify and consult in good faith with the potentially affected state.

First, the customary nature of the obligation to conduct an environmental impact assessment has been consecrated by the ICJ in the Pulp Mills case: 'a practice, which in recent years has gained so much acceptance among States that it may now be considered a requirement under general international law to undertake an environmental impact assessment where there is a risk that the proposed industrial activity may have a significant adverse impact in a transboundary context, in particular, on a shared resource'.56 Moreover, the Court adds that 'due diligence, and the duty of vigilance and prevention which it implies, would not be considered to have been exercised, if a party planning works liable to affect the regime of the river or the quality of its waters did not undertake an environmental impact assessment on

53 South China Sea Arbitration (n 23), at [964-965].

54 According to these Articles: 'The provisions of this Convention regarding the protection and preservation of the marine environment do not apply to any warship, naval auxiliary, other vessels or aircraft owned or operated by a State and used, for the time being, only on government non-commercial service. However, each State shall ensure, by the adoption of appropriate measures not impairing operations or operational capabilities of such vessels or aircraft owned or operated by it, that such vessels or aircraft act in a manner consistent, so far as is reasonable and practicable, with this Convention'. See B Oxman, 'Le régime des navires de guerre dans le cadre de la Convention des Nations Unies sur le droit de la mer' (1982) 28 Annuaire français de droit international 811-850, at p. 819; https://www.persee.fr/docAsPDF/afdi_0066-3085_1982_num_28_1_2519.pdf.

55 Ibid., at p. 832. [It would be difficult to secure acceptance of a military exercise causing substantial damage to an important natural resource that the coastal state is currently exploiting.]

56 Pulp Mills on the River Uruguay (n 40), at [204]. 
the potential effects of such works'.57 This customary obligation is also part of the LOSC. According to Article 206:

[w] hen States have reasonable grounds for believing that planned activities under their jurisdiction or control may cause substantial pollution of or significant and harmful changes to the marine environment, they shall, as far as practicable, assess the potential effects of such activities on the marine environment and shall communicate reports of the results $[\ldots]^{6}$.

Nevertheless, in this provision, it is necessary to have a clarification of the adjectives substantial and significant.

According to the 1991 Espoo Convention, the environmental impact assessment should contain not only a description of the activity and its likely impact, but also mitigation measures, practical alternatives and any uncertainties in available knowledge.58 One important but contentious issue is the question of cumulative impact assessment: how can account be taken of past or other pollutant activities already taking place or having taken place in the same area? A cumulative assessment, indeed, is the only means to make a precise evaluation of the real impact of an activity on the environment. It has been developed by the Secretariat of the Convention on biological diversity through the concept of 'strategic impact assessment', 59 and is currently part of the discussions regarding the adoption of a new implementing agreement of the LOSC on marine biodiversity conservation and sustainable use in areas beyond national jurisdiction. 60

Second, as the ICJ recalls in the Costa Rica v. Nicaragua case, 'if the environmental impact assessment confirms that there is a risk of significant transboundary harm, a State planning an activity that carries such a risk is required to notify, and consult with, the potentially affected State in good faith, where that is necessary to determine the appropriate measures to prevent or mitigate that risk'.61 These obligations of consultation and notification are to be found in Principle 19 of the 1992 Rio Declaration: 'States shall provide prior and timely notification and relevant information to potentially affected States on activities that may have a significant adverse transboundary environmental effect and shall consult with those States at an early stage and in good faith'. LOSC Article 198, dealing with '[n]otification of imminent or actual damage', also consecrates this environmental obligation, as does Article 204(2) which states additionally that '[i]n particular, States shall keep under surveillance the effects of any activities which they permit or in which they engage in order to determine whether these activities are likely to pollute the marine environment'. The obligations of consultation and notification are part, then, of the environmental customary international law principles applicable when there is a risk of transboundary damage, and are directly included in the 'due diligence' obligation regarding the protection and preservation of

57 Ibid., at [197]; Certain Activities Carried Out by Nicaragua in the Border Area (n 38), at [104]: 'to fulfil its obligation to exercise due diligence in preventing significant transboundary environmental harm, a State must, before embarking on an activity having the potential adversely to affect the environment of another State, ascertain if there is a risk of significant transboundary harm, which would trigger the requirement to carry out an environmental impact assessment'.

${ }_{58}$ Convention on Environmental Impact Assessment in a Transboundary Context (Espoo, Finland, 25 February 1991, in force 10 September 1997) 1989 UNTS 309. See Appendix II on the Content of the environmental impact assessment.

59 See Decision VIII/28 adopted at the 8th Conference of the Parties, 2006, UNEP/CBD/COP/8/27/Add.2, p. 23. 60 See, for instance, IISD Reporting Services, Summary of the fourth session of the preparatory committee on marine biodiversity beyond areas of national jurisdiction: $10-21$ July 2017, at p. 13, available at http://enb.iisd.org/oceans/bbnj/prepcom4/, accessed 20 September 2018.

${ }_{61}$ Certain Activities Carried Out by Nicaragua in the Border Area (n 41), at [168]. 
the marine environment. These elements are codified in the 2001 International Law Commission Articles on Transboundary Harm.62 For instance, according to Article 6, the 'State of origin shall require its prior authorization for the conduct of activities not prohibited by international law which involve a risk of causing significant transboundary harm' 63 .

The criterion of the 'significant transboundary harm' also deserves a concrete interpretation or a threshold to be set. In the meantime, it clearly corroborates the hypothesis put forward in the introduction on the 'question of degree': up until a certain point, military activities are to be tolerated in the EEZ of a coastal state. However, if the (ideally cumulative) environmental impact assessment and consultation with the coastal state reveal a risk of substantial damage or interference with the sovereign rights and environmental interests of the coastal state, the state conducting the activity must desist. Finally, a link can also be made here with the precautionary principle, as it is the risk of causing damage that is considered.

Some practical difficulties still remain: for instance, distinguishing between procedural and substantive obligations, as was done by the ICJ in the Pulp Mills case, and focusing on the procedural obligations included in the prevention principle and 'due diligence' requirements, is a way to bypass the difficulty of taking environmental damage into account in international law, especially in the EEZ. Some obstacles are nonetheless inherent in the field of international environmental law, such as the difficulty in evaluating the impact, the damagewhere appropriate - and the threshold. Birnie et al. explain that 'significant damage' 'implies both a degree of probability and a threshold of seriousness of harm, although the risk does not have to be ultra-hazardous in character', confirming the importance of conducting an impact assessment.64 It is also important to mention that an exemption for military activities is often part of the regimes governing MPAs or other conservation measures.

\section{Adaptation of this Framework to Non-Experimental and Non-Peaceful Military Activities}

As regards other military activities - non-experimental or non-peaceful (peacekeeping, armed conflict, or other operational military activity) - the framework developed above is a priori applicable. Indeed, there is not only a presumption of applicability of environmental conventions in time of war, 65 but also a presumption of applicability of customary law and general obligation of prevention and due diligence, 66 despite some necessary adaptations.

In the ICJ advisory opinion on the Legality of the threat or use of the nuclear weapons, 1996, the prevention principle was recalled, and the Court added: 'States must take environmental considerations into account when assessing what is necessary and proportionate in the pursuit of legitimate military objectives. Respect for the environment is one of the elements that go to assessing whether an action is in conformity with the principles of necessity and proportionality'.67 However, uncertainty surrounds the scope of application of the Protocol Additional to the Geneva Conventions of 12 August 1949 and of 8 June

62 International Law Commission, Prevention of Transboundary Harm from Hazardous Activities, Official Records of the General Assembly, Fifty-sixth Session, Supplement n 10 (A/56/10).

63 Ibid, ar Article 6. p. 2.

64 Birnie et al. (n 47), at p. 179.

65 Mollard-Bannelier (n 48), at pp. 266 and 273. See also Resolution 47/37 of the UNGA, 25 November 1992, and 1992 and 1993 Reports on the Protection of the environment in times of armed conflicts (available on the International Committee of the Red Cross (ICRC) website at https://www.icrc.org/eng/resources/documents/report/5deesv.htm, accessed 20 September 2018). Iran and Iraq had both invoked the violation of the Kuwait Regional Convention for Cooperation on the Protection of the Marine Environment from Pollution (Kuwait City, 24 April 1978, in force 30 June 1979) 1140 UNTS 133, according to which states must take all the appropriate measures to prevent, diminish and combat pollution in the maritime area of the Convention.

66 Mollard-Bannelier (n 48), at p. 321.

${ }_{67}$ Legality of the Threat or Use of Nuclear Weapons, Advisory Opinion [1996] ICJ Rep 226, p. 242, at [29-30]. 
197768, especially of its Article 55 regarding the protection of the natural environment, according to which

[c]are shall be taken in warfare to protect the natural environment against widespread, long-term and severe damage. This protection includes a prohibition of the use of methods or means of warfare which are intended or may be expected to cause such damage to the natural environment and thereby to prejudice the health or survival of the population.

It has been observed that this provision is not intended to be directly implemented as regards damage at sea, as some uncertainties pertaining to the scope of the legal framework for naval war still remain.69 For this reason, the San Remo Manual on International Law Applicable to Armed Conflicts at Sea70 has been developed. It recalls that in the EEZ and the continental shelf, '[d]ue regard shall also be taken to the protection and preservation of the marine environment', and that '[d]amage to or destruction of the natural environment not justified by military necessity and carried out wantonly is prohibited'.71

As regards activities related to peace-keeping, in its Resolution 2240, the Security Council of the United Nations notably 'calls upon Member States and regional organizations carrying out activities under paragraphs 7, 8 and this paragraph, to provide for the safety of persons on board as an utmost priority and to avoid causing harm to the marine environment or to the safety of navigation'.72 This sentence, which is of a legally binding nature, is highly significant. The reference to the obligation not to cause harm to the marine environment is indeed of an accessory or contingent character: the Security Council, which did not have to mention it in a resolution dealing with the urgent situation of the migrations in the Mediterranean Sea, thereby illustrates its erga omnes and customary character.

Nonetheless, although the 'due diligence' obligation applies in theory in situations of armed conflict or peacekeeping operations, it must be adapted, in practice, to those particular circumstances. According to Mollard-Bannelier, 'les obligations associées au principe de prévention [...] nécessitent d'être réadaptées en raison des circonstances particulières que représentent les conflits armés'.73 As far as environmental impact assessments are concerned, for instance, the impact of weapons or of methods of war on the environment should be evaluated in advance in order to avoid any significant damage, as it can be difficult to comply with this obligation in times of emergency. Meanwhile, the cooperation and notification obligations are not really compatible with a context of warfare. The possibility of adapting each obligation in the context of war is therefore to be appraised on a case-by-case basis.

\footnotetext{
68 Protocol Additional to the Geneva Conventions of 12 August 1949, and relating to the Protection of Victims of International Armed Conflicts (Protocol I) (Geneva, 8 June 1977, in force 7 December 1978) 1125 UNTS 3. 69 Ibid.

70 International lawyers and naval experts convened by the International Institute of Humanitarian Law, San Remo Manual on International Law Applicable to Armed Conflicts at Sea (Livorno, 12 June 1994), available at https://ihl-databases.icrc.org/ihl/INTRO/560?OpenDocument.

71 San Remo Manual on International Law Applicable to Armed Conflicts at Sea (12 June 1994), at [35 and 44]. See also at [11]: 'The parties to the conflict are encouraged to agree that no hostile actions will be conducted in marine areas containing: (a) rare or fragile ecosystems; or (b) the habitat of depleted, threatened or endangered species or other forms of marine life'; and also ED Papastavridis, 'The Use of Force at Sea in the $21_{\text {st }}$ Century: Some Reflections on the Proper Legal Framework(s)' (2015) The Journal of Territorial and Maritime Studies 119-138.

72 Maintenance of international peace and security, S/RES/2240 (2015), [10].

73 Mollard-Bannelier ( $\mathrm{48}$ ), at p. 340. [the obligations associated with the principle of prevention ... need to be readapted because of the particular circumstances of armed conflicts.]
} 


\section{Conclusion}

All in all, it is possible to stress the coherence of the global legal framework regarding the protection of the marine environment, which limits the exercise of military activities by noncoastal states in the EEZ. There can be no doubt that the protection and preservation of the marine environment is of particular importance and that it entails specific obligations or consequences, such as the conduct of environmental impact assessments and the obligation to notify and cooperate in good faith whenever an activity may cause environmental damage.

This approach to conciliating two different categories of rights, interests and duties, is, finally, to be appraised through the prism of marine spatial planning, a process aimed at concretely planning and conciliating all different human uses of the sea across borders and sectors, to ensure that human activities at sea are well combined and conducted in an efficient, safe and sustainable way. 74 